\title{
IMPACT OF GROUND WATER MARKETS IN CHANGING CROPPING PATTERN IN RAJASTHAN STATE
}

\author{
VIKASH PAWARIYA ${ }^{1}$, R. C. SHARMA ${ }^{2} \&$ B. K. SHARMA ${ }^{3}$ \\ ${ }^{I}$ Research Scholar, Department of Agricultural Economics, SKN College of Agriculture, Jobner, Jaipur, India \\ ${ }^{2}$ Professor \& Head, Department of Agricultural Economics, SKN College of Agriculture, Jobner, Jaipur, India \\ ${ }^{3}$ Professor, Department of Agricultural Statistics, SKN College of Agriculture, Jobner, Jaipur, India
}

Present investigation was carried out in the arid and semi arid district of Rajasthan state to analyze the Impact of Ground Water Markets in Changing Cropping Pattern in Rajasthan State. For this, primary data were collected with the help of pre structures schedule in the study area. Total sample size was 230 farmers. The farmers were classified in different categories on the basis of water transaction nature. The changing cropping pattern were found Buyers being the small and marginal farmers, preferred to grow food crops like wheat and bajra in higher proportion of GCA to fulfill their food and fodder requirement. Owners of WEMs preferred to grow mustard in higher proportion of GCA. The cropping intensity was highest for buyer and other categories were almost similarly low respectively.

KEYWORDS: Cropping Pattern, Groundwater Markets \& Cropping Intensity
\end{abstract}

Received: Jun 15, 2017; Accepted: Jun 30, 2017; Published: Jul 05, 2017; Paper Id.: IJASRAUG201715

\section{INTRODUCTION}

Agriculture is India's largest user of water as it is evident from the fact that Total utilizable water resource in the country has been estimated to be about 1123 BCM (690 BCM from surface and 433 BCM from ground), which is just $28 \%$ of the water derived from precipitation. About $85 \%$ (688 BCM) of water usage is being diverted for irrigation, which may increase to $1072 \mathrm{BCM}$ by 2050. Major source for irrigation is groundwater. The annual groundwater recharge is about $433 \mathrm{BCM}$ of which 212.5 BCM used for irrigation and 18.1 BCM for domestic and industrial use (CGWB, 2011). Groundwater irrigation, which expanded rapidly in the last few decades, has rapidly emerged to occupy a dominant place in India's agriculture and food security. It accounts for over 61 per cent of the irrigated area in the country (MOA, 2008-09). Groundwater is a vital resource, with a large fraction of the population relying on the resource directly or indirectly for livelihoods. The heavy reliance on groundwater for both domestic water and irrigation purposes is now approaching its limit as an increasing number of aquifers reach unsustainable levels after decades of exploitation. A crisis situation now exists in a number of states. In India, the stage of ground water development is 61 percent (CGWB, 2014). The gravity of the situation can be appreciated from the fact that the proportion of overexploited blocks nationwide has tripled from 5\% to $15 \%$ between 1995 and 2009.

The term 'water markets' describes a localized, village-level informal arrangement through which owners of a modern water extraction mechanism (WEM) sell water to other farmers at a price. Groundwater has contributed significantly to the development of Indian agriculture, particularly during the last four decades. It has been responsible for attaining food security through green revolution, commercialization of farming and promoting 
equity. Its exploitation in India is largely in the hands of private individuals and its development has grown exponentially over the years. The introduction of short duration, high -yielding crops along with intensive application of fertilizers, pesticides and mechanization enabled farmers to adopt multiple cropping practices that increased cropping and irrigation intensity substantially. Further, the advantages of groundwater irrigation coupled with favorable government policies and market forces induced farmers to intensify well irrigation and convert vast dry land areas of water intensive commercial crops. Thus the demand for groundwater increased remarkably. (Sharma \& Sharma, 2002)

The previous studies and present study show that Rajasthan passed the stage of groundwater development already and as data show that 70 per cent blocks are over exploited. Therefore, the management of existing resources for the better productivity in the study area is needed. Groundwater resources in the state are being over drafted and this tendency is really crucial to think. Further, the main occupation is agriculture, which cannot be spared at any cost even non availability of water and WEM. So the purchasing and selling of water for the regular agricultural operations is existing. This leads the emergence of Groundwater markets. The cropping pattern will show the difference in the state of Rajasthan.

\section{METHODOLOGY}

\section{The Study Area and Sampling Frame}

As the groundwater markets practices are prevalent in the overexploited and critical blocks of the country (CGWB), study area was selected on the basis of it.

Following the multi-stage sampling technique, the farmers were selected from eight villages of four districts from arid and semi-arid regions of Rajasthan. Jodhpur and Nagaur for the arid region and Sikar and Jaipur for the semi-arid region was selected purposively. These districts are categorized as an over - exploited stage of groundwater development. For each selected district, one block from the over-exploited category of blocks was selected randomly with the help of the Block Development Officer and Assistant Agriculture Officer of concerned block, where the buying and selling of groundwater was in practice. From the list, a cluster of two villages was selected randomly from each selected block. In sum total eight villages were selected for the present study.

A list of farmers was prepared from each village with the help of village patwari, leader Sarpanch and the villagers and the farmers were categorized into self users, self-users + sellers, self-users + sellers + buyer, buyers and nonusers groups or forms of water markets. From each forms or groups of farmers, fifteen per cent or more farmers were selected randomly. After selection of buyer category was again classified as self users + buyers and buyers for better comparison of data. In this way, 108 farmers from semi-arid region and 122 farmers from an arid region with the whole sum of 230 farmers were selected as depicted in table 1.

Table 1: Numbers of Farmers Selected from Selected Districts of Semi-Arid and Arid Regions of Rajasthan (2015-16)

\begin{tabular}{|c|c|c|c|c|c|c|c|c|}
\hline \multirow[t]{3}{*}{ Category } & \multicolumn{5}{|c|}{ Semi Arid Region } & \multicolumn{3}{|c|}{ Arid Region } \\
\hline & \multirow{2}{*}{$\begin{array}{c}\text { Jaipur } \\
\text { Total }\end{array}$} & \multicolumn{2}{|c|}{ Sikar } & \multicolumn{3}{|c|}{ Nagaur } & \multicolumn{2}{|c|}{ Jodhpur } \\
\hline & & Selected & Total & Selected & Total & Selected & Total & Selected \\
\hline Self-Users & 100 & 15 & 48 & 7 & 60 & 9 & 75 & 12 \\
\hline SU+ Sellers & 70 & 12 & 60 & 9 & 80 & 12 & 85 & 13 \\
\hline $\mathrm{SU}+\mathrm{S}+\mathrm{B}$ & 65 & 9 & 50 & 7 & 50 & 8 & 60 & 9 \\
\hline Buyers* & 130 & 20 & 118 & 18 & 100 & 15 & 180 & 27 \\
\hline Non-Users & 40 & 6 & 35 & 5 & 70 & 12 & 88 & 13 \\
\hline Total Selected & & 108 & & & & 122 & & \\
\hline
\end{tabular}


* Buyers further categorized as Self-users + Buyer and Buyer category of groundwater market

\section{Collection of Data}

The present study is based mostly on primary data. The primary data were collected through well structured, pretested and comprehensive schedules exclusively prepared for the study from the farmer by personal interview method. The schedules used for the primary data collection were designed based on the objectives of the study. Some district level information and rules and regulations on groundwater exploitation and other basic information were collected from the ground water department and various published or unpublished sources of Government of Rajasthan. The primary data were taken for agricultural year 2015-16 for the study.

\section{Analysis of Data}

This part deals with the tools and methods of analysis of data collected from farmers.

The study was based on the primary data collected from sample farmers during the agricultural year 2015-16. The study was adequately supported by the secondary information collected from the relevant government departments.

Simple tabular analysis was followed to examine the determinants of the groundwater markets.

\section{RESULTS AND DISCUSSIONS}

Type of soil, size of holding, availability of irrigation facilities and other resources, marketing facilities, etc. with the climatic conditions mainly influences the cropping pattern within an Agra-climatic region. The cropping pattern provides information regarding the intensity with which farmers were using their land and other resources. The cropping pattern followed by farmers under different forms of water market is presented in table 2.

\section{Overall for Rajasthan}

Table 2 revealed that mustard crop occupied highest fraction of gross cropped area followed by wheat in winter season and guar and bajra in rainy season. Mustard and guar being high value crops and also low water requiring or unirrigated crops, and wheat and bajra being the food crops dominated the cropping pattern in the study area. The other crops grown in smaller proportion were cumin and gram in winter season, and green gram and tomato in the summer. An evaluation of the cropping pattern across different forms of water market showed that owners of WEMs particularly selfusers and sellers in the water, preferred to grow in mustard in higher proportion (26.50 percent) of gross cropped area which is low

Table 2: Cropping Pattern Across the Water Markets in Rajasthan (2015-16)

\begin{tabular}{|c|c|c|c|c|c|c|}
\hline Particulars & SU & $\mathbf{S U}+\mathbf{S}$ & $\mathrm{SU}+\mathrm{S}+\mathrm{B}$ & SU+B & B & NU \\
\hline \multicolumn{7}{|c|}{ Percent Share of Crops in Gross Cropped Area } \\
\hline Wheat & 21.355 & 21.88 & 22.015 & 20.435 & 29.66 & 0 \\
\hline Barley & 1.295 & 1.54 & 1.48 & 2.605 & 0 & 0 \\
\hline Mustard & 26.505 & 24.415 & 25.68 & 24.48 & 19.605 & 15.27 \\
\hline Green gram & 5.195 & 5.645 & 4.745 & 5.495 & 3.51 & 3.215 \\
\hline Moth Bean & 1.775 & 2.02 & 1.64 & 1.64 & 0.765 & 0.745 \\
\hline Gram & 1.66 & 1.89 & 1.575 & 1.55 & 1.05 & 0 \\
\hline Guar & 16.355 & 15.85 & 16.56 & 15.15 & 10.875 & 24.7 \\
\hline Bajra & 16.075 & 15.43 & 14.95 & 15.74 & 19.215 & 41.94 \\
\hline Groundnut & 2.775 & 3.335 & 3.32 & 4.235 & 6.045 & 0 \\
\hline Cumin & 2.825 & 3.6 & 3.45 & 3.285 & 4.51 & 14.13 \\
\hline
\end{tabular}




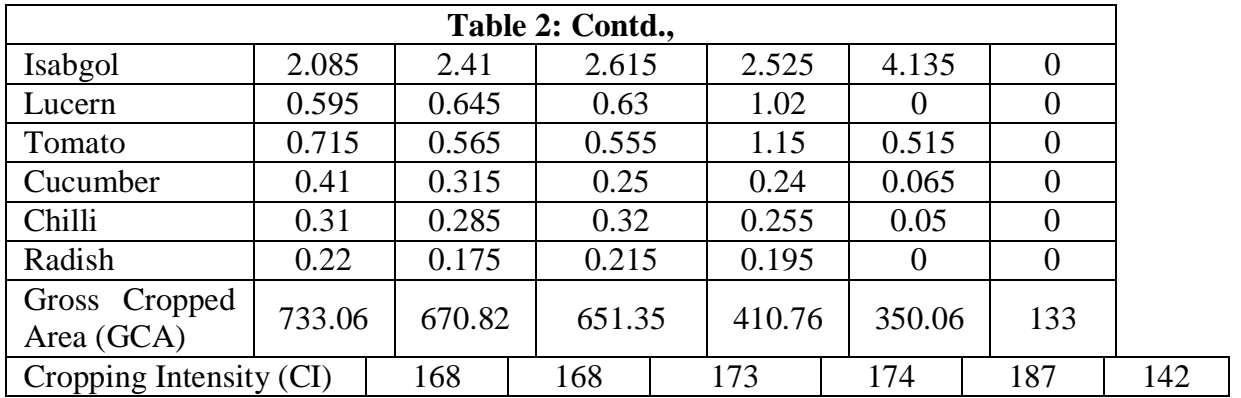

$\mathrm{S}$ for Seller, SU for Self user, B for Buyer and NU for Non-users category of Groundwater in water

Water and low labor requiring high value crop whereas buyers were growing wheat (29.66 percent) in higher proportion to fulfill the food and fodder requirement. Cumin and isabgol was cash crops in the winter and buyers were used to grow in the higher proportion. Bajra and guar is the crop which requires only life saving irrigation or none become of rainfed crop, bajra crop was grown by buyers about 19.21 per cent of GCA whereas by self users 16.07 per cent of GCA to fulfill the food and fodder requirements. 16.35 percent guar crop was grown by self users. Buyers were growing groundnut in higher proportion than self users because groundwater required by groundnut is the perception of the farmer. Non users of water market category in the absence of access to groundwater for irrigation took only unirrigated mustard (15.27 percent of GCA), guar (24.70 percent of GCA), bajra (41.94 percent of GCA), cumin (14.13 percent of GCA) and green gram (3.21 percent of GCA) as rainfed crops where bajra dominated the cropping pattern.

The cropping intensity was found highest for the buyer's category of water market (187 percent) whereas it is lowest for non users (142 percent) form of water markets. Similar results were found in the study of Sharma 2002, Khanna (2007), Srivastava et al (2009) and Srivastava and Kumar (2015) Self users and self users + sellers have the cropping intensity almost similar. Buyers have the highest cropping intensity because of the practice of intensive use of resources in their land holding.

\section{Semi Arid Region}

In the semi arid region, wheat and mustard in rabi season and guar and bajra in rainy season were major crops, other crops which were grown in small fractions of GCA were barley \& gram in winter season and green gram, moth bean, groundnut, tomato, cucumber, chilli and radish in summer season.(table 3)

Wheat was preferred by buyers form of water market (37.22 percent of GCA) with small land holding to fulfill the food and fodder requirements while mustard was being grown preferably by owners of WEMs about one fourth area of gross cropped area. Bajra is also preferred by the buyer's category of farmers than other water market forms. Groundnut crop was major irrigated crop in summer season and buyers put a higher proportion (6.69 percent) of the GCA under this. The tomato is grown by self user + buyer form of water market ( 2.30 percent) mainly followed by self user and buyers category of farmer respectively.

Table 3: Cropping Pattern across the Water Markets in Semiarid Region of Rajasthan (2015-16)

\begin{tabular}{|l|c|c|c|c|c|c|c|}
\hline \multicolumn{1}{|c|}{ Particulars } & SU & SU+S & SU+S+B & SU+B & B & NU \\
\hline \multicolumn{7}{|c|}{ Percent Share of Crops in Gross Cropped Area } \\
\hline Wheat & 26.05 & 26.22 & 26.34 & 25.15 & 37.22 & 0 \\
\hline Barley & 2.59 & 3.08 & 2.96 & 5.21 & 0 & 0 \\
\hline Mustard & 27.54 & 28.01 & 28.07 & 25.56 & 21.48 & 30.54 \\
\hline Green gram & 1.24 & 1.32 & 1.29 & 0.84 & 0 & 0 \\
\hline
\end{tabular}




\begin{tabular}{|l|c|c|c|c|c|c|}
\hline \multicolumn{7}{|c|}{ Table 3: Contd., } \\
\hline Moth Bean & 1.32 & 1.38 & 1.24 & 0.93 & 0 & 0 \\
\hline Gram & 3.32 & 3.78 & 3.15 & 3.1 & 2.1 & 0 \\
\hline Guar & 15.51 & 15.25 & 16.2 & 16.05 & 11.58 & 34.14 \\
\hline Bajra & 16.2 & 15.64 & 15.1 & 16.42 & 19.67 & 35.32 \\
\hline Groundnut & 2.35 & 2.02 & 2.26 & 2.04 & 6.69 & 0 \\
\hline Lucern & 0.57 & 0.62 & 0.71 & 1.02 & 0 & 0 \\
\hline Tomato & 1.43 & 1.13 & 1.11 & 2.3 & 1.03 & 0 \\
\hline Cucumber & 0.82 & 0.63 & 0.5 & 0.48 & 0.13 & 0 \\
\hline Chilli & 0.62 & 0.57 & 0.64 & 0.51 & 0.1 & 0 \\
\hline Radish & 0.44 & 0.35 & 0.43 & 0.39 & 0 & 0 \\
\hline Gross Cropped Area (GCA) & 373.06 & 280.57 & 296.2 & 230.34 & 119.56 & 64.6 \\
\hline Cropping Intensity (CI) & 172 & 171 & 175 & 178 & 190 & 145 \\
\hline
\end{tabular}

$\mathrm{S}$ for Seller, SU for Self user, B for Buyer and NU for Non user's category of Groundwater in water

Non users of water in the absence of access to irrigation water grow bajra (35.32 percent of GCA) followed by guar (34.14 percent of GCA) and mustard (30.54 percent of GCA). Bajra was the dominated cropping pattern for non user's category of water markets.

The highest cropping pattern was found for buyers (190 percent) and lowest for non-users (145 per cent). Buyers being the farmers of small category have the highest cropping intensity and non users in the absence of access to irrigation water were not using resources intensively. The cropping pattern was found almost similar to other forms of water markets.

\section{Arid Region}

Similarly, in arid region also mustard dominated the cropping pattern followed by wheat, bajra and guar. Other crops grown in small proportion were cumin, green gram, moth bean, groundnut, isabgol and lucern. Owners of WEMs preferred to put more area to mustard (25.47 percent of GCA) and guar (17.2 per cent of GCA) while buyers preferred to grow wheat (22.1 per cent of GCA) cumin (9.02 percent of GCA), isabgol (8.27 per cent of GCA), bajra (18.76 per cent of GCA) and groundnut (5.4 per cent of GCA) to fulfill the demand for food and market. (Table 4)

The cropping intensity was found to be higher (186 per cent) for a buyer's form of water market and lowest for non-users (165 percent) for all other forms of water markets, the cropping intensity was found to be almost similar.

Table 4: Cropping Pattern across the Water Markets in Arid Region of Rajasthan (2015-16)

\begin{tabular}{|l|c|c|c|c|c|c|c|}
\hline \multicolumn{1}{|c|}{ Particulars } & SU & SU+S & SU+S+B & SU+B & B & NU \\
\hline \multicolumn{7}{|c|}{ Percent Share of Crops in Gross Cropped Area } \\
\hline Wheat & 16.66 & 17.54 & 17.69 & 15.72 & 22.1 & 0 \\
\hline Cumin & 5.65 & 7.2 & 6.9 & 6.57 & 9.02 & 28.26 \\
\hline Isabgol & 4.17 & 4.82 & 5.23 & 5.05 & 8.27 & 0 \\
\hline Bajra & 15.95 & 15.22 & 14.8 & 15.06 & 18.76 & 48.56 \\
\hline Guar & 17.2 & 16.45 & 16.92 & 14.25 & 10.17 & 15.26 \\
\hline Green gram & 9.15 & 9.97 & 8.2 & 10.15 & 7.02 & 6.43 \\
\hline Moth Bean & 2.23 & 2.66 & 2.04 & 2.35 & 1.53 & 1.49 \\
\hline Groundnut & 3.2 & 4.65 & 4.38 & 6.43 & 5.4 & 0 \\
\hline Mustard & 25.47 & 20.82 & 23.29 & 23.4 & 17.73 & 0 \\
\hline Lucern & 0.62 & 0.67 & 0.55 & 1.02 & 0 & 0 \\
\hline Gross Cropped Area (GCA) & 360 & 390.25 & 355.15 & 180.42 & 230.5 & 68.4 \\
\hline Cropping Intensity (CI) & 165 & 166 & 172 & 170 & 186 & 140 \\
\hline
\end{tabular}

$\mathrm{S}$ for Seller, SU for Self user, B for Buyer and NU for Non users category of Groundwater in water 


\section{CONCLUSIONS}

It may be concluded from the above discussion that mustard and wheat in winter season and bajra and guar in summer season were the major crops. Farmers of the study area were growing less water intensive crops. Other high value crops were cumin, isabgol, groundnut, green gram and tomato. Buyers being the small and marginal farmers, preferred to grow food crops like wheat and bajra in a higher proportion of GCA to fulfill their food and fodder requirement. Owners of WEMs preferred to grow mustard in a higher proportion of GCA. Buyers in assuring irrigation water were growing high value crops. Non users, in the absence of access to irrigation water were growing unirrigated mustard in winter and bajra and guar in summer season. The cropping intensity was highest for buyer and other categories were almost similarly low respectively.

\section{REFERENCES}

1. Sharma, P., (2002). "Implications of Groundwater Markets on Farm Economy in Rajasthan", unpublished Ph.D. thesis, Department of Agricultural Economics, Rajasthan Agricultural University, Bikaner (Campus: Jobner)

2. Khanna Gauri (2007). "Improving Agricultural Efficiency Amongst groundwater users: the case of sugarcane in north india". Journal of Public \& International Affairs. Vol. 18, p80

3. Srivastava, $S$ K and Kumar, $R$ (2015) “Groundwater extraction for use efficiency in crop production under different water market regimes: A case study of Uttar Pradesh state (India)”. Water Management in Agriculture. , pp. 125-139.

4. Srivastava S.K. ; Kumar Ranjit and Singh R.P.(2009). "Extent of Groundwater Extraction and Irrigation Efficiency on Farms under Different Water-market Regimes in Central Uttar Pradesh". Agricultural Economics Research Review Volume : 22, Issue : 1 